\title{
KULTUROWE UJĘCIE ZAGADNIENIA OBIEKTYWIZMU BADAŃ EKONOMICZNYCH
}

\begin{abstract}
Streszczenie
Celem tekstu jest próba przedstawienia kategorii obiektywizmu i kategorii obiektywności wiedzy ekonomicznej z perspektywy społeczno-regulacyjnej koncepcji kultury oraz stanowiska konstruktywizmu kulturowego.

Słowa kluczowe: postulat obiektywizmu, zasada obiektywności wiedzy naukowej, kontekst kulturowy, wyobrażenie świata obiektywnego, wartości-sensy, konstruktywizm kulturowy, konstruktywizm społeczny

\section{OBJECTIVITY OF ECONOMICS RESEARCH FROM THE CULTURAL PERSPECTIVE}

\section{Summary}

The main aim of this paper is to reconstruct the meaning of two philosophical categories: objectiveness and objectivity in scientific economic practice. The research is based on the perspective of social-regulative concept of culture and the standpoint of cultural constructivism.
\end{abstract}

Key words: principle of objectivity and objectiveness, cultural context, values-senses, cultural constructivism, social constructivism

JEL: B, B41

\section{Wstęp}

Respektowanie zasady obiektywizmu wiedzy naukowej to jeden z najważniejszych postulatów i zarazem inwariantów metodologicznych nakładanych na praktykę badawczą. Postulat ten, jak wiadomo, stanowi bazę posługiwania się kryterium intersubiektywnej kontrolowalności - a w konsekwencji społecznościom badaczy umożliwia przyjmowanie w obszar nauki - bądź odrzucenie poza jej granice - danego systemu przekonań. Procedura akceptacji bądź dezakceptacji wiedzy naukowej odwołuje się również 
do kryterium obiektywności - dlatego też poszerzono problematykę podaną w tytule tekstu o kwestię sposobu ujmowania oraz respektowania tej zasady.

Postulat obiektywizmu oraz ściśle z nim powiązany postulat obiektywności wiedzy przybierały różnorodne formy w dziejach nauki nowożytnej, a w kontekście toczących się dziś dyskusji na temat kryzysu poznawczej prawomocności wiedzy ekonomicznej - nabrały szczególnego znaczenia. Zagadnienie obu tych postulatów autorka zamierza rozpoznać z perspektywy teoretycznej autorstwa Jerzego Kmity, tj. historycznej teorii wiedzy naukowej i społeczno-regulacyjnej koncepcji kultury oraz wywodzącego się z tych ujęć stanowiska konstruktywizmu kulturowego.

Sposób ujęcia zagadnienia obiektywizmu i obiektywności wiedzy naukowej zależy od szeregu przyjętych założeń filozoficznych o charakterze ontologicznym i epistemologicznym, w tym od koncepcji prawdziwości, prawomocności czy poznawczej trafności przekonań oraz źródeł tak pojmowanej i orzekanej wiedzy naukowej. Jest to pogląd znany i powszechnie podzielany. Jednakże przeświadczenie, że oba te postulaty (obiektywizmu oraz obiektywności), których postaci zostały ukształtowane na podstawie danego - przyjętego w społeczności uczonych - sposobu rozpoznawania oraz oceny wartości poznawczej proponowanych rozstrzygnięć, mają również zasadniczy wpływ na charakter praktycznych (technologicznych) efektów wiedzy naukowej powstałej w danym kontekście kulturowym - nie jest już tak oczywiste, a przynajmniej nie zawsze uwzględniane explicite w sytuacji, gdy tenże sposób postrzegania świata (na przykład dziedziny gospodarowania) cieszy się uprzywilejowana pozycja. Wszakże w obszarze ekonomii, postać obowiązującej, a szczególnie dominującej teorii funkcjonowania gospodarki czy przedsiębiorstwa, znacząco decyduje (zwłaszcza jeśli jest w stanie eliminować bądź marginalizować koncepcje alternatywne) o rozstrzygnięciach o pozapoznawczym charakterze, tj. o rodzaju uchwytnych praktycznie następstw w sferze polityki gospodarczej, pieniężnej bądź społecznej. Innymi słowy, postulat obiektywizmu oraz obiektywności w konsekwencji wpływa na treść promowanych i realizowanych norm i reguł gospodarowania - i co najważniejsze - na aksjologiczne wybory podejmowane w odniesieniu do hierarchii kulturowych wartości-sensów praktyki społeczno-gospodarczej. Warto w tym miejscu podkreślić, że w społeczności badaczy-ekonomistów zakładających inne niż - obecnie dominujące - scjentystyczne założenia teorii ekonomicznych narasta świadomość tego typu zależności. Najnowszym przykładem jest idea „Reforma kulturowa 2020, 2030, 2040” [Równiej, 2015].

Z tego właśnie względu należy uznać, że samo zagadnienie oraz treść koncepcji obiektywizmu i obiektywności badań ekonomicznych należą dziś do zasadniczych pytań nauk ekonomicznych, w tym zwłaszcza ekonomii.

\section{Kategoria obiektywności wiedzy ekonomicznej}

Kategoria obiektywności wiedzy naukowej wiąże się z podstawowym dla filozofii nauki, epistemologii czy teorii wiedzy zagadnieniem typu relacji wiazżącej formułowane na poziomie języka etnicznego (naukowego) wypowiedzi z obszarem, którego te wypowie- 
dzi dotyczą. Najczęściej owa relacja jest przedstawiana w kontekście dwóch występujących łącznie kryteriów. Pierwsze z nich wyraża się w pytaniu: która ze sfer związanych $z$ relacja jest pierwotna, która zaś wtórna, natomiast kryterium drugie dotyczy kwestii, czy owo powiązanie winno pojmować się w sensie relacji przyczynowo (stany rzeczy w świecie) - skutkowej (użycia „słów”) czy relacji semantycznej (koncepcji odniesienia przedmiotowego), [Kmita, 1995, s. 5-10 i s. 210-211].

Jeśli chodzi o kryterium pierwotności versus wtórności odnośnych sfer, to można stwierdzić, że koncepcje należące do ujęć o charakterze przedmiotowym uznają za obiekt swego poznania, ujawniająca się na poziomie „czystego” bezzałożeniowego opisu, „obiektywną" rzeczywistość, również tę, którą określa się mianem gospodarowania. Tym samym badanej sferze nie przypisuje się żadnych dodatkowych własności (a zwłaszcza tych, które wynikałyby z samego procesu poznawczego czy uwikłania podmiotu w kontekst kulturowy), zakładając, że tak pojmowany „obiektywny” opis jest możliwy i że zasadnicze pytanie dotyczy tego, w jaki sposób powinien być dokonywany, aby był możliwie trafny, wiernie odzwierciedlający cechy badanych przedmiotów oraz zachodzących między nimi zależności. Jak wiadomo, owo reprezentacjonistyczne (a zarazem dualistyczne: podmiot versus przedmiot poznania) ujęcie jest charakterystyczne dla wszelkich - związanych z pozytywistycznym (i z pewnymi zastrzeżeniami - hipotetystycznym) paradygmatem - stanowisk, które podzielają scjentystyczne przekonanie o prawomocności orzekania o istnieniu tak rozpoznawanej sfery będącej przedmiotem poznania i o możliwości jej mniej lub bardziej dokładnego odtworzenia. Ujęciom tym, co oczywiste, towarzyszy klasyczna (korespondencyjna) koncepcja prawdy. Jak zauważa Stachak: Nadrzedna cecha wiedsy naukowej jest prawdziwość. Stanowi ona kryterium kwalifikowania wy-

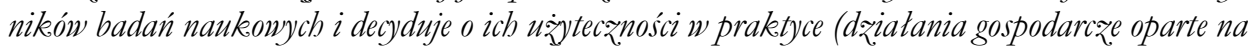
nieprawdziwej wiedsy sa z reguly nieefektywne). W naukach ekonomicznych jako empirycznych obowiazuje klasyczne kryterium prawdy. Podlegaja mu zdania o poznawalnych rzeczach $i$ zjawiskach gospodarcsych oraz ich oceny utylitarne, crylli tylko takie stwierdzenia, ketóre dotycza faktón terażniejssych i minionych oraz w petni zdeterminowanych faktón praysszlych [Stachak, 2006, s. 19].

Przekonanie o możliwości uzyskania bezpośredniego bądź pośredniego kontaktu ze zmysłowo ujawniającą się, obiektywną rzeczywistością charakteryzuje różnorodne postaci realizmu filozoficznego (epistemologicznego). Hardt, autor interesującej pracy poświęconej zagadnieniom realistycznej filozofii ekonomii, stwierdza, że Warunkiem mo:̀liwości poznania jest jednak to, aby poznawalne istniato, by to dostępe dla podmiotu poznajacego i od niego niezależne. Ten warunek to nic innego, jak postulat realizmu naukowego, a jednym z.najważniejszych argumentów za jego urnaniem jest sukces nauki w ostatnich stuleciach - gdybyśmy bo-

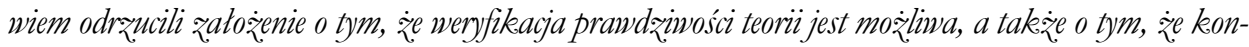
strukty teoretyczne maja empiryczne desygnaty, wownczas sukces nauki musiałby zostaćpo prostu u₹nany za «cud». (...) Nie jest więc mo:̀liwa refleksja nad nanka bez. odniesienia sie do realizmu [Hardt, 2013, s. 7]. W tym rozumieniu, teorie ekonomii tzw. głównego nurtu przyjmuja że określone stany rzeczy, np.: uniwersalistycznie pojmowane motywacje podmiotów i cele przedsiębiorstwa, rozwój gospodarczy czy bezrobocie, to bezpośrednio bądź pośrednio dostępne, obserwowalne świadectwo albo wystarczające potwierdzenie funkcjonowania określonych mechanizmów rozpoznawanych jako obiektywne (tj.: pozaspołeczne, pozakulturowe), stałe i niezmienne. Zgodnie z przyjętym założeniem scjentystycznego 
paradygmatu wiedzy, praktyka gospodarowania podlega takim samym prawidłowościom, jak rzeczywistość przyrodnicza (jest jej częścia, jest wobec niej wtórna). Dlatego też ekonomiści, którzy podzielają stanowisko realizmu filozoficznego, przyjmuja tym samym, że efektywność dziedziny techniczno-użytkowej (kierowanej regułami techniczno-użytkowej sfery kultury), która jest praktyka gospodarcza: zaleşy myłacznie od tego, cay odnośne dyrektyny z dostatecznym prayblizeniem «odgadwja» odpowiadajace im zwiazki prayczynowe [Kmita, 1995, s. 275]. Związki przyczynowe, które są konstytuowane przez prawidłowości (obiektywnej) rzeczywistości.

Zatem scjentystyczny paradygmat uprawiania badań ekonomicznych wraz z koncepcją obiektywizmu wiedzy naukowej zakłada pierwotność badanej sfery, czyli doświadczenia wobec jej pojęciowej reprezentacji na poziomie języka etnicznego i powiazzanie między obiema sferami pojmuje w sensie relacji przyczynowo (stany rzeczy w świecie) - skutkowej (użycia „słów”).

Tak rozumiana relacja obiektywności (wyłączenie procesu poznania z obszaru kultury) jest przy tym wyrazem obecnego w kulturze Zachodu tzw. mitu epistemologicznego w sensie L. Kołakowskiego - uprawomocnionego i utrwalonego zwłaszcza dzięki koncepcjom filozoficznym I. Kanta. Zdaniem Kołakowskiego, zalegitymizowanie sytuacji badawczej oraz uprawomocnienie wspólnoty ludzkiej poprzę jej odniesienie do wspólnego środowiska rzeczowego, wymagaja mitycznej opcii zawartej w prayjeciu kategorii «istnienia» w sensie niewarunkonym, tj. zawartej w postawieniu i rozstrayganiu pytania epistemologicznego [Kołakowski, 1974, s. 34].

Owa mityczna świadomość nakazuje nam rozumieć obecność świata jako istniejacego w tym właśnie niewarunkowym sensie.

Natomiast stanowiska tworzące ujęcia kulturowe przyjmują, że przedmiotem poznania praktyki badawczej nie jest pojmowana na wzór obiektywistyczno-scjentystyczny, niezależna od społecznego kontekstu, rzeczywistość, lecz konstytuowana przez wielość - zależnych od kulturowego układu pojęć i przekonań (tzw. przedsemantycznych charakterystyk świata w sensie J. Kmity) - wizja owej rzeczywistości. Kategoria obiektywności nie przysługuje zatem pojmowanym literalnie desygnatom pojęć, które są obecne w sąach / zdaniach tworzonych przez uczonych, i które to desygnaty miałyby odpowiadać określonym stanom rzeczy w przedmiotowo rozpoznawanym świecie. W tym sensie, relacja między pojęciami a ich desygnatami, relacja odniesienia pržedmiotowego ma charakter wewnatrajesylkony, ogólniej - wewnatrzkulturowy [Kmita, 1995, s. 282]. $\mathrm{Z}$ ujęcia kulturowego, w znaczeniu J. Kmity, wywodzi się stanowisko konstruktywizmu historycznego, które przyjmuje explicite, że ką̇da kultura operuje aytworzonym w niej pojeciem lub uyobrazeniem swniata, który dla ws yystkich partycypujacych w niej jest realny $i$ istnieje obiektymnie [Pałubicka, 2013, s. 97]. Warto dodać, że odniesieniem przedmiotowym w pojmowanej wewnątrzkulturowo relacji semantycznej między pojęciami a ich desygnatami są obiekty/ stany rzeczy, o których się komunikuje, w tym również i zwłaszcza językowo [Kmita, 1995, s. 285]. Co oczywiste, pierwotność w tak rozumianej relacji wiażacej wypowiedzi języka etnicznego (naukowego) z obszarem, którego te wypowiedzi dotycza, przysługuje sferze kultury, rzeczywistości myślowej, w której kształtuje się i funkcjonuje ludzki swiat obiektywny, ustalający granice i zawartość realnego istnienia świata (stanów rzeczy) danej społeczności. 
Kategorię obiektywizmu, zgodnie z ujęciem kulturowym, autorka przypisuje więc uformowanemu społecznie i ,wiążącemu" w danym czasie i w danej dziedzinie wyobrażeniu świata obiektywnego [Pałubicka, 1990, s. 9], w którego ramach poszczególne elementy uzyskują myślową reprezentację, zostają nazwane (tj. przełożone na pojęcia), co następuje w zakresie określonej przedmiotowej teorii naukowej bądź systemu światopoglądowego, np.: orientacji filozoficznej, epistemologicznej. W związku z tym, że odniesieniem przedmiotowym pojęć są tylko te obiekty/ stany rzeczy, o których się komunikuje, ujęcie kulturowe nie wypowiada się na temat obiektów, które takiej językowej reprezentacji nie uzyskały. Jak twierdzi Kmita, relacja odniesienia przedmiotowego nie wikła się w filozoficzny problem realizmu [Kmita, 1995, s. 282] i nie wymaga interpretacji ontologicznej. Jeśli coś istnieje, to tylko w sensie kulturowym, tzn. wówczas, gdy uzyskuje pojęciową artykulację.

Realne w sensie obiektywnego istnienia to zatem to, co pojawia się jako „ważne” w pojęciowym oglądzie gospodarki przyjętym w społeczności badaczy-ekonomistów: Kiedy mowa o realnym istnieniu, mam na myśli istnienie obiektywno-kulturowe, istnienie dla nas, dla danej wspólnoty [Pałubicka, 2013, s. 97]. Pojawia się jednak pytanie, kiedy i w jakich okolicznościach dochodzi do nadania określonym obiektom ze sfery gospodarowania statusu tego, co „ważne”. Z perspektywy ujęcia kulturowego [Pałubicka, 2013, s. 189] proces ten polega na przejściu od doznawanych przez podmiot (w tym przypadku jest nim badacz) wyobrażeń, uczuć, względnie emocji, w sferze jednostkowej do wymiaru społecznego, co oznacza uwspólnotowienie indywidualnie dotąd przeżywanych treści i wyobrażeń. Jednakże owo przejście nie jest aktem/ procesem dowolnym czy arbitralnie stanowionym - dokonuje się w ramach kultury danej społeczności lub środowiska i jest warunkowane przez funkcjonujące w tym obszarze normy i reguły (w przypadku społeczności badaczy będa to oczywiście normy i reguły o charakterze epistemologicznym i metodologicznym). Rzeczywistość myślowa, zwana kultura, może nie przyjąć owych jednostkowych wyobrażeń bądź eliminować czy zmarginalizować już uwspólnotowione pojęcia i związane z nimi systemy przekonań (czego dobitnym przykładem są tzw. orzeczenia paranaukowości w dziejach nauki lub przypadki współczesnych werdyktów o uwikłaniu danej-dazżacej do miana naukowej - koncepcji w sferę ideologii). Egzemplifikacją takiego procesu „rezygnowania” przez kulturę społeczności badaczy jest sytuacja stopniowego eliminowania kwestii etycznych z pola zainteresowań teorii ekonomii, mimo że A. Smith, twórca ekonomii jako dyscypliny naukowej, rozpoznawał je jako istotne dla opisu funkcjonowania gospodarki. Owa rezygnacja - jak wiadomo - łączyła się z narastaniem scjentystyczno-obiektywistycznego paradygmatu wiedzy ekonomicznej będącego częścią rozumu przyrodoznawczego [Pałubicka, 2013], zgodnie z którym zagadnienia moralne mają status wartości (stanów rzeczy) niejako z definicji nienależących do świata realnie istniejącego. Jeśli zatem obiekty mające status wartości są nadal usuwane z pola zainteresowań badaczy-ekonomistów, oznacza to prymat przyrodoznawczego rozumu.

W przypadku ekonomii mamy do czynienia z obiektami/ stanami rzeczy, których status jako tego, co „ważne”, bywa (w tym samym momencie historycznym) niejednorodny w zależności od perspektywy teoretycznej danej teorii ekonomicznej. Chodzi 
m.in. o kategorie, takie jak: rozwój gospodarczy, równowaga rynkowa, deregulacja gospodarki, efektywność rynku, elastyczność rynku pracy, stabilność makroekonomiczna, obniżenie inflacji, bezrobocie, wzrost konkurencyjności gospodarki/ przedsiębiorstw, maksymalizacja zysku, nierówności społeczne, spójność społeczna, ochrona środowiska przyrodniczego czy trwały zrównoważony rozwój. Na marginesie warto dodać, że uzasadnienie takiej sytuacji dyskursu naukowego, kiedy równocześnie pojawiają się tak różnorodne wartości-sensy gospodarowania, byłoby zadaniem niewykonalnym na gruncie scjentystyczno-obiektywistycznych koncepcji ekonomii opartych na reprezentacjonistycznej koncepcji poznania, nawet jeśli odwołano by się do procedur modelowania korzystających z założeń idealistycznej koncepcji nauki L. Nowaka. Zwolennikiem idealistycznej koncepcji nauki bądź stanowiska izolacjonizmu w ekonomii jest na przykład $\downarrow$. Hardt, który stwierdza, że rola modelowania jest myižolowanie istotnych czynników i mechanizmów odpowiadajacych za obserwowane zjawiska empiryczne [Hardt, 2013, s. 49].

Zastosowane w tekście pojęcie wartości-sensy zaczerpnięto z pracy A. Pałubickiej [Pałubicka, 2013, s. 51], która proponuje: odróżnić wartość-sens kulturony od celu driałania. Cel znika wraz zjego zrealizowaniem, natomiast wartość obowiazuje nadal i trwa w kulturze. Autorka artykułu przyjmuje, że wprowadzone rozróżnienie oznacza nie tyle technologiczna (uchwytna praktycznie) nierealizowalność określonych wartości (sytuacja ta dotyczy wartości nadrzędnych, to znaczy tych, które w większości dają się tylko pomyśleć: sprawiedliwość, ochrona praw człowieka, autonomia uczonych, nadrzędność refleksji teoretycznej nad wiedzą operacyjną itd.), ile wymóg powtarzalności, utrwalenia we wspólnocie pewnych pożądanych sposobów postępowania, czyli ukształtowania się społecznych praktyk ukierunkowanych na ciągłe dążenie ku tym wartościom (bądź na ich eliminowanie), a nie na przypadki ich jednorazowego, lokalnego osiagania.

Stanowisko konstruktywizmu kulturowego (szerzej: konstruktywizmu społecznego bądź konstruktywizmu bezppraymiotnikowego) jest obecnie przedmiotem wielu interesujących analiz, także w obszarze ekonomii [Zboroń, 2009; Scheuer, 2015]. Generalnie, stanowisko konstruktywizmu kulturowego przyjmuje, że przedmiotem ludzkiego poznania - nie tylko nauk społecznych i humanistycznych, lecz również przyrodniczych - jest świat wytworzony w toku spontanicznych interakcji społecznych ukształtowanych kulturowo (a zatem niedowolnie, ale zarazem niearbitralnie) i według wzorców kulturowych poznawany i doświadczany. Jak stwierdza Pałubicka: przedmiotem poznania może być jedynie swiat przez nas (ludzi, spoteczeństwo, wspólnote) skonstruowany wedle prayjetych wzorów. Poznajemy swiat, zjawiska, procesy udostepnione przez kulture [Pałubicka, 2013, s. 201]. Autorka wskazuje dwa podstawowe rodzaje konstruktywizmu: konstruktywizm epistemologiczny, który zakłada, że cała nasza wiedz̨a o swiecie jest nynikiem konstruowania, a nie odkrywania rzecsynistości oraz konstruktywizm kulturowy, który przyjmuje, że wytwarzamy: nie tylko wiedž, ale rónnieżpojecie swiata, które uprzedmiotowiamy i obiektywizujemy [Pałubicka, 2013, s. 201]. W tym rozumieniu konstruktywizm kulturowy to pogląd, który wyraża poziom metafilozoficznej samowiedzy czy samoświadomości dotyczącej myślenia o naszym myśleniu jako konstruktu społecznego, tworzonego i przebiegającego według społecznie przyjętych wzorów [Pałubicka, 2013, s. 103]. Umieszczając pojęcie konstruktywizmu kulturowego w szerszej perspektywie przemian wzorów kulturowych (gramatyki kultury) Zachodu, cytowana autorka zauważa, że wzór, który współcześnie 
jest obecny, skłania do pytania nie tylko o to, jak mamy myśleć o świecie, lecz właśnie: jak mamy myśléc o nassym (nytworzonym) myśleniu [Pałubicka, 2013, s. 199].

Dokładna rekonstrukcja filozoficznych założeń konstruktywizmu, w tym także konstruktywizmu społecznego oraz zachodzących między tymi stanowiskami różnic, wymagałaby pogłębionych analiz wykraczających poza ramy niniejszego tekstu. Zatem autorka tego artykułu wskaże jedynie charakterystykę stanowiska (beapprymmiotnikowego) konstruktywizmu zawartą w pracy Scheuera, który stwierdza, że konstruktymiżm odsyła w kewestiach wiedzy i poznania do spoleczności, w których to poznanie sie odbywa, a wiedza jest tworzona; oznacza to w dalszej kolejności, że fundamentem wiedzy staje sie w ten sposób kultura, a ostatecznie, że elementem koniecznym dla zrozumienia procesów poznawncyych jest ježy [Scheuer, 2015, s. 21].

Na marginesie warto zwrócić uwagę na to, że koncepcje konstruktywistyczne budza niepokój w naukach społecznych (oraz w sferze publicznej) - niewątpliwie jednym z powodów tego stanu rzeczy jest utrata przez nie, wspomnianego wcześniej, epistemologicznego mitu w sensie L. Kołakowskiego. Jak można sądzić, niepokój ów wzmacnia także obecność konkurencyjnych, wartościujących obrazów świata społecznego. Pozostając jednak w obszarze filozofii nauki, nie sposób nie zauważyć, że konstruktywizm kulturowy niekiedy jest utożsamiany $z$ konstruktywizmem społecznym, zwanym również konstruktywistycznym relatywizmem. Krytykę tego - tak rozumianego - stanowiska przedstawia A. Grobler: Konstruktywizm spoteczny jest pod pewnym wagledem odwróceniem empiryzmu logicznego. Ten drugi koncentrowat sie na metodologii nauk prayrodniçych i rozciagat ja na wszelkie nauki w ogóle. Ten pierwszy natomiast, sam postugujac sie stosowana w antropologii metoda obserwacii uczestniczacej, absolutyzuje metodologie nauk społecznych. Nie trzeba chyba jednak wyjaśniać, że jedno i drugie postepowvanie jest ranadto jednostronne [Grobler, 2006, s. 293].

Odnosząc kwestie ujęcia kulturowego oraz konstruktywizmu kulturowego do badań ekonomicznych, należy sformułować pytanie, na czym polega poznawcza „wyższość” owych ujęć wobec koncepcji scjentystyczno-obiektywistycznych. Autorka tego artykułu sądzi, że owa przewaga polega przede wszystkim na umiejętności rozpoznawania złożoności kulturowych uwarunkowań badań ekonomicznych i zakwestionowaniu współczesnej dominacji rozumu przyrodoznawczego. Obecny od trzech stuleci w kulturze Zachodu, współtwórca technologicznych i cywilizacyjnych sukcesów praktyki badawczej, w tym ekonomii, jest dziś krytykowany z racji zagrożeń i następstw, które niesie, a zwłaszcza za destrukcję hierarchii wartości wspólnotowych. Ujęcia kulturowe równocześnie uprawomocniają funkcjonowanie wszelkiego typu nurtów krytyczno-emancypacyjnych, pojawiających się dziś w refleksji nad społeczeństwem gospodarującym, legitymizuja projekty zmian oraz przekształcenia norm i reguł gospodarowania rozpoznawanych jako konstrukty kulturowe, wytwarzane i przyjmowane przez ludzi i społeczności - a nie jako reprezentacje niezależnych od świata społecznego mechanizmów i w konsekwencji norm i reguł niezmienialnych.

\section{Kategoria obiektywności wiedzy ekonomicznej}

Rozważania poświęcone kategorii obiektywizmu autorka pragnie uzupełnić krótką analizą kategorii obiektywności wiedzy ekonomicznej, jakkolwiek zdaje sobie sprawę, 
że może to spotkać się z zarzutem, iż przeprowadzanie tego rozróżnienia nie jest przydatne poznawczo, np. $z$ tego względu, że sami badacze często utożsamiają obie te kategorie. Egzemplifikacją tego typu terminologicznego zwyczaju czy uzusu są wypowiedzi Stachaka, który formułując postulat rzetelności ocen recenzyjnych, wykorzystuje zamiennie oba te pojęcia [Stachak, 2006, s. 285]. Potwierdzeniem tej kłopotliwej sytuacji terminologicznej jest również przykład z dziedziny refleksji etycznej. Dotyczy on znanego podziału sądów, tj. zdań na te, których prawdziwość, względnie prawomocność, odnosi się do przedmiotów i w tym sensie to one miałyby być zasadne, ponieważ są niezależne od czyichś pogląów, oraz na te, których prawomocności nie da się ustalić, gdyż są zależne od poglądów podmiotów - a zatem subiektywne [Encyklopedia Filozofii, 1999, s. 645]. Autorzy Stownika Socjologicznego [Stownik Socjologiczny, 2002, s. 143] analizując treść postulatu związanego ze stanowiskiem wolnym od uprzedzeń i stronniczości w badaniach naukowych, które powinno polegać na rzeczowości i właśnie bezstronności, także posługują się pojęciem obiektywizmu. Niewątpliwie, na poziomie języka potocznego obie te kategorie są często stosowane zamiennie i - przypuszczalnie - zwykle towarzyszy im konotacja pozytywna.

Jednakże, zgodnie $z$ ujęciem kulturowym, zabieg ten jest sensowny, dlatego że odwołuje się do klasycznych rozróżnień funkcjonujących już w społeczności uczonych. Ponadto, autorka uznaje, że rozumienie kategorii obiektywności wiedzy naukowej jest konsekwencja przyjętej koncepcji obiektywizmu tej formy wiedzy. Jak już wspomniano, kategoria obiektywizmu_odnosi się do typu relacji między wypowiedziami języka nauki a obszarem, którego owe akty mówienia dotyczą oraz do rozstrzygnięcia stosunku pierwotności versus wtórności obu sfer. Przedstawione koncepcje obiektywizmu, tj. scjentystyczno-obiektywistyczna konstytuująca stanowisko realizmu filozoficznego oraz kulturowa, implikują więc określone ujęcia kategorii obiektywności wiedzy naukowej.

Warto podkreślić, że kategoria obiektywności_najczęściej jest utożsamiana z pewnymi własnościami wiedzy ludzkiej (potocznej bądź naukowej) w sensie braku jej zdeterminowania czy uwarunkowania, a nawet zdeformowania przez przekonania, które do nauki nie należą, tj. przez przeświadczenia religijne lub polityczne i tym samym łączy się z postulatem intelektualnej autonomii uczonych. Bez watpienia, postulat ten wywodzi się z koncepcji odniesienia do wartości autorstwa Maxa Webera, a więc programu naukowości i obiektywizmu wiedzy humanistycznej, który - dzięki wskazaniu, że wprawdzie nauki humanistyczne zajmują się opisem i wyjaśnianiem sfery społecznej tworzonej przez wartości kulturowe - głosi, że odniesienie do wartości nie jest (nie powinno być) jednoznaczne $z$ wartościowaniem, tj. oceną badanych zjawisk. Weber, pisząc o etosie pracy naukowej akademickiego pedagoga, stwierdza: Wymagać mo:̇na od niego tylko intelektualnej uczciwości: zrozumienia, że z jednej strony ustalanie faktów, matematycznych cay logicznych stanów rzeçyy cay struktury wewnetrznej dóbr kulturalnych, z drugiej strony zaś odpowiedźn na pytanie o wartość kultury i sktadajacych sie na niaposzzrególnych treści, oraz na pytanie, jak naleșy postepować w obrebie kulturowej wspólnoty i politycznych organizacï - to dwa catkiem heterogeniczne problemy [Weber, 1999, s. 210-211]. 
Interesującym przykładem opinii dotyczącej problemu obiektywności i obecności sądów wartościujących w ekonomii jest stanowisko M. Blauga. Odwołując się do przeprowadzonego przez E. Nagela podziału sądów wartościujących na: charakteryzujące sądy wartościujące oraz oceniające sądy wartościujące, uczony konkluduje, że w ekonomii: Spór o fakty może wydawać sie możliny do zakończenia, a to drięei rozstraygajacemu świadectwu tak. zwanych faktów obiektywnych, podczas gdy spór o wartości moralne może zostać rozwiazany jedynie drięki bezpośredniemu odwołaniu sie do emocji, lecz. w ostatecznym rachunku oba

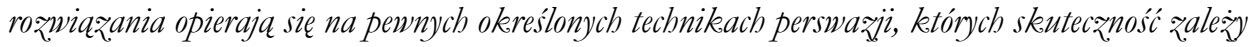
z. kolei od podzielanych przę strony takich, lub innych wartości [Blaug, 1995, s. 179-180]. Można uznać, że koncepcja Blauga, odwołująca się do emocji czy wartości, a więc stanów rzeczy znajdujących się poza nauką, nie umożliwia wyjaśnienia źródeł czy podstaw kierowania się danymi wartościami przez uczonych.

Kategoria obiektywności, która wiąże się z postulatem autonomii intelektualnej uczonych, w ramach społeczno-regulacyjnej koncepcji kultury jest określana mianem normy neutralizmu aksjologicznego wyników poznawczych: wartościowanie traktowane jest tutaj jako czyyność intelektualna pozbawiona możliwości uzasadniajacych, nie zaśs - ze w ogóle jest zabronione [Pałubicka, 1990, s. 16]. Praktyka badawcza, która stosuje normę neutralizmu aksjologicznego, cechuje się tym, że nie dokonuje wartościowań w wymiarze przedmiotowym (tj. nie ocenia badanych stanów rzeczy), natomiast zawsze - owe wartościowania występują na poziomie metodologicznym (i to właśnie norma aksjologicznego neutralizmu jest takim przykładem). Warto dodać, że również postać owego, uzasadnionego wartościowania podlega historyczno-dziedzinowej zmienności.

Jednak zasadniczy problem wyraża się w tym, że norma zachowania obiektywności wiedzy naukowej (w sensie braku jej zdeterminowania przez przekonania spoza nauki) nie jest tak po prostu możliwa do zrealizowania. Wiedza naukowa powstaje w określonym kontekście kulturowym, ten zaś - z definicji - jest zawsze sferą wartościowań. W związku z tym, nie chodzi tu o indywidualne, żywione przez badacza przekonania typu: stereotypy, przesądy, uprzedzenia, założenia religijne, które ujawniają się np. w krytyce genderstudies, lecz o założenia, które stoją za wyborem określonego paradygmatu w ekonomii. Z tego też powodu wypowiedź M. Blauga, sformułowana przy okazji analizy dyskusji na temat statusu ekonomii pozytywnej i normatywnej, głosząca, że Do postępu w nauce dochodżi tylko wtedy, kiedy dażymy do maksymalizowania znaczenia faktów i minimalizowania żnaczenia wartości [Blaug, 1995, s. 206] - nie jest przekonująca.

Analizując kategorię obiektywności w badaniach ekonomicznych, należałoby zatem powrócić do kwestii już omawianej, tj. obiektywizmu ekonomii. Obiektywizm wiedzy ekonomicznej jest rozumiany (jak już wspomniano) jako zagadnienie typu relacji wiążącej wypowiedzi na poziomie języka w postaci koncepcji i teorii przedmiotowych oraz badanego przedmiotu. Niewatpliwie, w przypadku ujęcia scjentystyczno-obiektywistycznego kategoria obiektywności będzie łączyć się z troską o uchronienie formułowanej wiedzy przed deformacjami (stereotypami, uprzedzeniami, przekonaniami politycznymi bądź religijnymi), które na gruncie tego poglądu płyną z uwarunkowań spoza nauki, a więc są czynnikami, które nie wynikają z samego procesu poznawania. Prawomocność tego procesu jest bowiem - w myśl tego ujęcia - zapewniona przez 
metodologicznie ustaloną procedurę odkrywania zjawisk i procesów obiektywnie funkcjonującej (pozakulturowej, pozaludzkiej) rzeczywistości gospodarczej. Natomiast zagrożeniem dla obiektywności wiedzy jest wspólnota, której badacz jest członkiem, i której pozanaukowe przedsądy mogą wpływać na podmiot poznający i w konsekwencji zniekształcać wiedzę o realnym świecie gospodarowania.

W perspektywie ujęcia kulturowego i konstruktywistycznego zagadnienie obiektywności wiedzy i badań ekonomicznych przyjmuje inny wymiar. Uznaje się, że obiektywność jako kategoria ma wymiar społecznie-historyczny, jest wzorem uprawiania nauki przyjętym i realizowanym świadomie bądź implicite w danej społeczności badaczy. Postulat zachowania obiektywności wiąże się zatem $z$ respektowaniem (praktykowaniem) właściwych dla danego paradygmatu (teorii) założeń o charakterze wartościującym, które jednak w ramach tego paradygmatu są przyjmowane jako prawomocne, oczywiste i pozbawione wartościowań na mocy przypisywanego im obiektywizmu w ramach wspólnoty badaczy. Innymi słowy, wartościowania dotyczące sfery gospodarowania, które z perspektywy ujęcia kulturowego są nieodzownym elementem systemów wiedzy nauk społecznych, w paradygmacie obiektywistyczno-scjentystycznym posiadaja status opisu obiektywnie istniejących stanów rzeczy i charakterystycznych dlań własności. Przykładowo: koncepcja homo oeconomicus w ekonomii neoklasycznej bądź idea „zwierzęcych instynktów" w ekonomii behawioralnej, pojmowana przez uczonych z odnośnych nurtów jako rezultat opisu obiektywnej realności, która jest natura ludzka, odgrywają rolę tego typu przesądzeń utrwalonych w społeczności i współtworzą założenia obrazu świata danej (neoklasycznej czy behawioralnej) teorii przedmiotowej ekonomii. Warto dodać, że perspektywa kulturowa będzie traktować owe przykładowe koncepcje jako rekonstrukcyjny opis historycznie zaistniałych wzorów kultury gospodarczej, tj. pożądanych i aksjologicznie uprawomocnionych w danym czasie i w danej wspólnocie sposobów postępowania jednostkowych podmiotów gospodarujących.

\section{Podsumowanie}

Zamiarem przedstawienia zagadnienia obiektywizmu i obiektywności wiedzy ekonomicznej z perspektywy koncepcji scjentystyczno-obiektywistycznych oraz ujęcia kulturowego i stanowiska konstruktywizmu kulturowego było wyeksponowanie pewnych efektów dyskusji toczących się w ramach filozofii ekonomii wokół współczesnej sytuacji tej dyscypliny wiedzy. Opowiedzenie się autorki niniejszego artykułu za perspektywą kulturowa jest powodowane, jak można sądzić, nie tylko intelektualnym przywiązaniem do pewnej perspektywy teoretycznej, lecz również przeświadczeniem, że jest to perspektywa, która - oprócz tego - że pozwala trafnie rozpoznawać społeczne uwarunkowania praktyki badawczej ekonomii, to stanowi także konceptualną podstawę przekształcania sfery gospodarowania zgodnie $z$ wypracowaną społecznie i uzgodnioną hierarchią wartości-sensów [Pogonowska, 2014]. Wskazana, teoretyczna podstawa przekształcania sfery gospodarowania nie tylko zapewnia realizowanie postulatu obiektywizmu i obiektywności wiedzy z zakresu ekonomii, ale jednocześnie uświadamia, że teoria ekonomiczna to konstrukt kulturowy i z tego właśnie względu jest w stanie zmieniać świat. 


\section{Literatura}

Blaug M., 1995, Metodologia ekonomii, Wydawnictwo Naukowe PWN, Warszawa. Encyklopedia Filozofii, 1999, T. Hondericha (red.), t. II, Wydawnictwo Zysk i S-ka, Poznań. Grobler A., 2006, Metodologia nank, Wydawnictwo Aureus, Wydawnictwo Znak, Kraków. Hardt L., 2013, Studia ₹ realistycznej filozofii ekonomii, Wydawnictwo C.H. Beck, Warszawa. Kmita J., 1995, Jak stowa tacza sie ze swiatem, Wydawnictwo Naukowe Instytutu Filozofii Uniwersytetu im. Adama Mickiewicza w Poznaniu, Poznań.

Kołakowski L., 1974, Obecność mitu, https://www.scribd.com/doc/ (data wejścia: 16.09.2015).

Kołakowski L., 1974, Obecność mitu, Instytut Literacki, Paryż.

Olechnicki K., Załęcki P., 2002, Stownik Socjologiczny, Wydawnictwo Graffiti BC, Toruń.

Pałubicka A., 1990, Kulturowy wymiar ludzkiego świata obiektywnego, Wydawnictwo Naukowe Uniwersytetu im. Adama Mickiewicza, Poznań.

Pałubicka A., 2013, Gramatyka kultury europejskiej, Oficyna Wydawnicza Epigram, Bydgoszcz.

Pogonowska B., 2014, Wspótczesna treśćpojecia wroru kultury gospodarczej, [w]: Wrory kultury gospodarczej, W. Banach (red.), „Człowiek i Społeczeństwo”, XXXVIII, Wydawnictwo Naukowe Uniwersytetu im. Adama Mickiewicza, Poznań.

Rómniej, 2015, wywiad z prof. E. Mączyńską, „Gazeta Wyborcza” 6-7 czerwca.

Scheuer B., 2015, Metodologia ekonomii w perspektywie konstruktywistycznej, Wydawnictwo Uniwersytetu Ekonomicznego we Wrocławiu, Wrocław.

Stachak S., 2006, Podstany metodologii nauk ekenomicznych, Wydawnictwo „Książka i Wiedza", Warszawa.

Weber M., 1999, Nauka jako zawód i powołanie, [w]: Z. M. Weber, Z. Krasnodębski, Wydawnictwo „Wiedza Powszechna”, Warszawa.

Zboroń H., 2009, Teorie ekonomiczne w perspektywie poznawczej konstruktywižmu społecznego, Wydawnictwo Uniwersytetu Ekonomicznego w Poznaniu, Poznań. 